\title{
Ensayo cometa: una prueba necesaria para la detección de genotoxicidad en profesionales de la salud
}

\author{
Comet test: a necessary test for the detection of genotoxicity in health \\ professionals
}

Roberto Edgar Alex Farroñán-Sondor 1a, Luis Miguel Serquén-López ${ }^{2 b}$

\section{Sr. Editor}

Al año se registran 41000000 de fallecimientos a nivel mundial, causados por enfermedades no transmisibles; de ellos 9000000 son por cáncer. El 70\% de fallecimientos se registran en países con ingresos medios y bajos. Estudios indican que varios tipos de cáncer podrían estar asociados con la exposición a contaminantes en circunstancias de exposición ambiental y ocupacional. Asimismo, algunos medicamentos como los citostáticos, utilizados para el tratamiento del cáncer, interactúan con el ADN o sus precursores, inhibiendo la síntesis del nuevo material genético; resultando en la pérdida de la capacidad de replicación celular. El problema es ocupacional, por cuanto las personas expuestas a estas sustancias genotóxicas (citostáticos, radiaciones, reactivos de laboratorio...), son los profesionales de la salud, principalmente en los servicios de oncología, farmacia, patología clínica e imágenes ${ }^{\left({ }^{1}\right)}$. El objetivo de la presente carta es informar la necesidad de implementar pruebas, como el ensayo cometa, que permitan vigilar a los profesionales de salud expuestos a citostáticos.

En los hospitales, el uso de varios medicamentos requieren de la ejecución de procedimientos previos (formulaciones, reconstitución, mezclas, disoluciones...), realizados por el personal de salud, quienes se exponen mediante la inhalación de aerosoles y vapores, así como la penetración a través de la piel y mucosas ${ }^{(2)}$. La exposición crónica a estos medicamentos puede ocasionar efectos mutagénicos, carcinogénicos y teratogénicos. El interés de que los profesionales expuestos sean vigilados de cerca es por las siguientes razones ${ }^{(3)}$ :

1. La existencia de una estrecha relación entre la inestabilidad genómica de células somáticas con el cáncer y las enfermedades degenerativas crónicas.

2. El incremento en el grado de mutación de las células germinales (óvulos, espermatozoides y gametocitos), lo cual puede provocar el aumento de la incidencia de las enfermedades genéticas en futuras generaciones.

\section{El origen ambiental del cáncer.}

Para detectar la exposición ocupacional a agentes genotóxicos se han desarrollado diferentes métodos (4); pero es la técnica de electroforesis en gel de células individuales o "ensayo cometa", una de las más empleadas para evidenciar el daño inducido en el ADN. En esta prueba las roturas o fragmentación del material genético ocasionados por estos agentes se apreciará semejando la cola de un cometa; así pues, ante la acción de un genotóxico, se espera tener imágenes con "cabezas" de información intacta y "colas" con material afectado; por el contrario, en células sin daño se espera obtener solo "cabezas" o núcleos sin la existencia de "colas" (5).

En términos de monitorización biológica ocupacional se puede aplicar el ensayo cometa a cualquier tipo de células, sobre todo en piel y mucosas, que están expuestas directamente con sustancias genotóxicas. Además, debido a sus múltiples ventajas como: su rápida realización (pocas horas), el pequeño tamaño de muestra requerido, aplicabilidad a cualquier población de células y su alta sensibilidad; es que el en-

\footnotetext{
1. Facultad de Ciencias de Biológicas, Universidad Nacional Pedro Ruiz Gallo, Lambayeque, Perú.

2. Laboratorio de Biología Molecular, Hospital Regional Lambayeque, Chiclayo, Peú.

3. Facultad de Medicina Humana, Universidad San Martín de Porres, Chiclayo, Perú.

a. Biólogo Microbiólogo.

b. Biólogo.
} 
sayo cometa se está empleando con frecuencia y constituye una de las pruebas más importantes en la genética toxicológica ${ }^{(6)}$. El ensayo cometa presenta ventajas frente a otros ensayos de genotoxicidad como las técnicas de citogenética convencional (aberraciones cromosómicas, el intercambio de las cromátidas hermanas y la prueba de micronúcleos); razón por el cual es sugerida y aplicada en estudios de cáncer, evaluación de genotoxicidad ambiental y ocupacional y prevención de la exposición a productos químicos ${ }^{(6)}$.

A pesar de la importancia del ensayo cometa en la vigilancia biológica del riesgo genotóxico en el personal de salud, no es aplicado en los hospitales a nivel nacional, abriendo la posibilidad de desarrollar efectos locales y sistémicos, a corto y largo plazo ${ }^{(7)}$.

Finalmente, se propone implementar la prueba del ensayo comenta como examen ocupacional en todo profesional de la salud que tenga contacto con agentes genotóxicos, en particular trabajadoras en periodo gestacional. La vigilancia de la genotoxicidad en el personal expuesto deberá realizarse previo consentimiento informado y en el marco de un programa anual o tras alguna exposición accidental.

\section{REFERENCIAS BIBLIOGRÁFICAS}

1. Organización Panamericana de la Salud. Estado de la salud de la población, Prevención y control de las enfermedades no transmisibles; c 2017 [citado en 2017]. Salud en las Américas [Aprox 3 pantallas]. Disponible en: https:// www.paho.org/salud-en-las-americas-2017/?post_t_es=prevencion-y-control-de-las-enfermedades-no-transmisibles\&lang=es

2 Montero $\mathrm{H}$, Rodríguez $\mathrm{M}$, et al. Monitoreo de seguridad ocupacional en el manejo de citostáticos. Journal of Pharmacy \& Pharmacognosy Research. 2018; 6(6): 433-447.

3 Oltulu C, Cagatay T, et al. Evaluation of Genotoxicity Risk in Health Care Workers Exposed to Antineoplastic Drugs. Clinical and Experimental Health Sciences. 2019; 9(2): 166-170.

4 Broto M, Roger G, and M-Pilar M. Bioanalytical methods for cytostatic therapeutic drug monitoring and occupational exposure assessment. TrAC Trends in Analytical Chemistry. 2017; 97: 152-70.

5 Koppen G, Azqueta A, Pourrut B, Brunborg G, Collins A, \& Langie S. The next three decades of the comet assay: a report of the 11th International Comet Assay Workshop. 2017; 6: 397-408.

6 Langie S, Azqueta A, \& CollinsR. The comet assay: past, present, and future. Frontiers in genetics. 2015; 6: 266

7 Tipacti A, et al. Peligros y riesgos en los profesionales de la salud expuestos a citostáticos en el servicio de quimioterapia de un hospital nacional, Lima. [Trabajo Académico para optar el Título de Segunda Especialidad en Enfermería en Salud Ocupacional]. Lima: Facultad de enfermeria de la Universidad Peruana Cayetano Heredia; 2017.

Revisión de pares: Recibido: 12/09/2019 Aceptado: 10/10/2019 